\title{
Morphology and stability of aggregates of an Oxisol according to tillage system and gypsum application
}

\author{
Fábio Régis de Souza ${ }^{1}$, Edgard Jardim Rosa Junior ${ }^{2}$, Carlos Ricardo Fietz ${ }^{3}$, Douglas Martins Pereira Pellin ${ }^{4}$, \\ Anderson Cristian Bergamin ${ }^{5}$, Evandro Gelain 6 , Yara Brito Chaim Jardim Rosa
}

\begin{abstract}
Morphological characterization and aggregate stability is an important factor in evaluating management systems. The aim of this paper is to evaluate the stability and morphology of the aggregates of a dystrophic Oxisol managed with no-tillage and conventional tillage with and without the residual action of gypsum. The experimental design was randomized blocks arranged in split-split plot, where the treatments were two soil management systems (plots) with 0 and $2000 \mathrm{~kg} \mathrm{ha}^{-1}$ of gypsum (subplots) and five depths (0-0.05, 0.05-0.10, 0.10-0.15, 0.15-0.20 and 0.20-0.30 m) as the subsubplots, with four replications. The aggregate morphology was determined through images and later evaluated by the Quantporo software. Stability was determined by the wet method. The results showed that the no-tillage system, with or without gypsum residual effect, provided the aggregates with the largest geometric diameters. The combination of no-tillage system and the gypsum residual effect provided rougher aggregates.
\end{abstract}

Key words: soil structure, gypsum, til

\section{RESUMO}

\section{Morfologia e estabilidade de agregados de um Latossolo em função do manejo e da gessagem}

A caracterização morfológica e a estabilidade dos agregados constituem fatores importantes na avaliação dos sistemas de manejo. O objetivo deste trabalho foi avaliar a morfologia e a estabilidade de agregados de um Latossolo Vermelho distroférrico, manejado com plantio direto e plantio convencional, com e sem ação residual de gesso. $\mathrm{O}$ delineamento experimental foi em blocos casualizados, arranjado em esquema de parcelas subsubdivididas, em que os tratamentos foram dois sistemas de manejo do solo, (parcelas) e com 0 e $2000 \mathrm{~kg} \mathrm{ha}^{-1}$ de gesso (subparcelas) e cinco profundidades $(0-0,05,0,05-0,10,0,10-0,15,0,15-0,20$ e 0,20-0,30 m) sendo as subsubparcelas, com quatro repetições. A morfologia dos agregados foi determinada por meio de imagens e, posteriormente, avaliada pelo software Quantporo; a estabilidade foi determinada pelo método da via úmida. Os resultados demonstram que o cultivo em sistema plantio direto, com ou sem efeito residual de gesso, proporcionou maiores diâmetros geométricos de agregados. A combinação entre plantio direto e efeito residual de gesso proporcionou agregados mais rugosos.

Palavras-chave: estrutura do solo, gessagem, preparo do solo.

\footnotetext{
Received for publication on June $06^{\text {th }}, 2012$ and approved on October $31^{\text {th }}, 2012$.

${ }^{1}$ Agronomist engineer, Doctor. Centro Universitário da Grande Dourados, Rua Balbina de Matos, 2121, Jardim Universitário, 79824-900, Dourados, Mato Grosso do Sul, Brasil. fabioagronomo@yahoo.com.br (autor correspondente).

${ }^{2}$ Agronomist engineer, Doctor. Faculdade de Ciências Agrárias, Universidade Federal da Grande Dourados, Rodovia Dourados-Itahum, Km 12, 79804-970, Dourados, Mato Grosso do Sul, Brasil. jjr.jr@Ufgd.edu.br

${ }_{3}^{3}$ Agronomist engineer, Doctor. Empresa Brasileira de Pesquisa Agropecuaria, BR 163, Km 253,6, 79804-970, Dourados, Mato Grosso do Sul, Brasil. fietz@cpao.embrapa.br

${ }^{4}$ Agronomist engineer. Master degree student at Universidade Estadual de Mato Grosso do Sul, Unidade Universitária de Aquidauana, Rodovia Aquidauana-Cera, Km 12, 79200-000, Aquidauana, Mato Grosso do Sul, Brasil. douglas.martins@agronomo.eng.br

${ }_{5}^{5}$ Agronomist engineer, Doctor. Departamento de Agronomia, Universidade Federal do Amazonas, Avenida General Rodrigo Octávio Jordilio Ramos, 3000, Campus Universitário, Coroado L Manaus, Amazonas, Brasil. andersonbergarnin@hotmail.com

${ }^{6}$ Agronomist engineer, Master. Universidade Federal da Grande Dourados, Rodovia Dourados-ltahum, Km 12, 79804-970, Dourados, Mato Grosso do Sul, Brasil. evandro gelain@ @otmail.com ${ }^{7}$ Agronomist engineer, Doctor. Faculdade de Ciências Agrárias, Universidade Federal da Grande Dourados, Rodovia Dourados-ltahum, Km 12, 79804-970, Dourados, Mato Grosso do Sul, Brasil.yararosa@ufgd.edu.br
} 


\section{INTRODUCTION}

The anthropic impact on ecosystems has been a major factor for land degradation, through practices that cause rapid disintegration, rainfall effects and the direct action of agricultural machinery, changing the structure of macro and microaggregates (Lacerda et al., 2005; Gajic et al., 2006). The destruction of soil aggregates can be considered as the beginning of the erosion process and this has been used as an index of erodibility (Castilho et al., 2008).

The dynamics of aggregation results from an interaction of factors that include the environment, root growth, mineral composition of the soil texture, soil organic carbon, pedogenic processes, climatic factors, microbial activity, nutrient reserves, variation in the soil moisture and leaching of ions (Smucker \& Horn, 2005; Pulleman et al., 2005, Bronick \& Lal, 2005).

The management, use and duration of soil use promote different changes in soil properties, such as structure, which is related to the aggregation. The changes in aggregation caused indirectly affect other physical properties such as density, porosity, aeration, the retention capacity and water infiltration (Bayer \& Mielniczuk, 1999).

Water stable aggregates contribute to improving the porosity and thereby greater infiltration and erosion resistance (Matos et al., 2008). The unstable aggregates, when on the surface, tend to disperse and disappear under the impact of raindrops (Assis \& Bahia, 1998).

According to Calonego \& Rosolem (2008), soil aggregation can be induced, as the roots exert pressure on the mineral particles during its growth in the pore space, promoting the approximation of the particles.

Besides aggregation induced by roots, the stability of aggregates is also determined by cementing agents such as organic matter and iron oxides (hematite and goethite), aluminum (gibbsite) and calcium. (Shainberg \& Levy, 1995; Silva \& Kato, 1997, Albuquerque et al., 2000).

Gypsum is one of the main sources of calcium of a relatively low cost. Its effects on the flocculation of soil particles reflect in the improvements of soil structure and aggregation (Rosa Junior et al., 1994; Rosa Junior et al., 2006, Souza et al., 2010).

Types of soil management are characterized by the continuous intake of plant waste and minimum soil disturbance by practising conservation tillage, which favours the improvement and conservation of soil aggregates, while the management with preparation by ploughing pulverizes the surface layer and promotes rapid decomposition of crop residues added to the soil, as in the conventional tillage, with ploughing and harrowing, reducing the stability of aggregates and increasing the rate of organic matter oxidation (D'Andrea et al., 2002).
Cremon (2007) discuss that the use of digital analyses to measure the quality of the soil allows the characterization of the aggregates according to their geometric shapes, using measures and indices of micromorphometry. Olzeviski et al. (2004) and Cremon (2007) also argue that the soil structure represents its own constitution, as expressed by the size, shape and distribution, or the arrangement of empty spaces and primary or secondary solid particles.

Understanding and quantifying the impact of the use and management of soil in its structural quality are fundamental in the development of sustainable agricultural systems. Therefore, the objectives of this work were to evaluate the morphology and stability of soil aggregates subjected to two types of managements and the residual effect of gypsum.

\section{MATERIAL AND METHODS}

The study was conducted in an experimental field of the Faculty of Agricultural Sciences, Federal University of Grande Dorados, located at the coordinates $22^{\circ} 12^{\prime} \mathrm{S}$ and $54^{\circ} 56^{\prime} \mathrm{W}$, with $452 \mathrm{~m}$ of attitude. The climate, according to Köppen classification, is of type $\mathrm{C}_{\mathrm{wa}}$. The soil of the experimental site is classified as Oxisol (Embrapa, 1999), originally under cerrado vegetation in the transition zone with the rainforest. The area has not been previously cultivated and the current predominant vegetation is a mix of grasses.

The natural vegetation was initially incorporated into the soil by ploughing and harrowing.

The granulometric composition of the soil, wich was determined by the pipette method (Embrapa, 1997), was: $644 \mathrm{~g} \mathrm{~kg}^{-1}$ clay, $203 \mathrm{~g} \mathrm{~kg}^{-1}$ silt and $153 \mathrm{~g} \mathrm{~kg}^{-1}$ of sand, within the first $0.20 \mathrm{~m}$.

The experiment was conducted in a randomized block design with a split-split plot arrangement: the treatments consisted of management (tillage and conventional tillage, the plots); gypsum doses of 0 and $2000 \mathrm{~kg} \mathrm{ha}^{-1}$ (split plots) and five layers $(0-0.05,0.05-0.10,0.10-0.15,0.15-0.20$ and $0.20-0.30 \mathrm{~m}$ ) as the split-split plots, with four replications.

In August 2003, after the soil analysis, liming was performed in all treatments to raise the $\mathrm{pH}$ to 6.5 . In the treatment with gypsum, the lime was broadcasted and incorporated with harrows, in the first 2 weeks of October 2003.

Three test pits $(0.50 \mathrm{~m}$ wide x $0.50 \mathrm{~m}$ long x $0.40 \mathrm{~m}$ deep) were excavated in each plot for soil sample collections. The plot size was $4050 \mathrm{~m}^{2}$. In the conventional tillage system, the operations consisted of a primary prepare with an intermediary harrowing and a secondary prepare with a levelling harrowing. The operations of soil preparation were always conducted before the sowing of 
the crops, in the harvests of 2003/2004, 2004/2005, 2005/ $2006,2006 / 2007$ and $2007 / 2008$. The species grown over this period were, in succession, soybean/corn and soybean/oat.

To determine aggregate stability, samples were collected from the soil in the pits, with the structure preserved, in the study layers of each plot. After being air dried and clod crushed by hand, the fraction that passed through a sieve with $9.52 \mathrm{~mm}$ mesh and was retained on the $4.76 \mathrm{~mm}$ mesh was separated. The stability of aggregates was obtained by sieving in water, using a vertical oscillator of amplitude of $0.08 \mathrm{~m}$ and frequency of 40 oscillations per minute, based on Kemper \& Chepil (1965) and the adaptations proposed by Reicherdt et al., 1993; Embrapa, 1997; Castro Filho et al., 1998 and Palm et al., 1999.

The separate fractions corresponded to aggregates > $8.00 \mathrm{~mm} ; 8.00$ to $6.00 \mathrm{~mm} ; 6.00$ to $4.00 \mathrm{~mm} ; 4.00$ to $2.00 \mathrm{~mm}$; 2.00 to $1.00 \mathrm{~mm} ; 1.00$ to $0.50 \mathrm{~mm} ; 0.50$ to $0.25 \mathrm{~mm} ; 0.25$ $0.105 \mathrm{~mm}$ and $<0.105 \mathrm{~mm}$. With these values, it was calculated the mean weight diameter (MWD) by the equation 1, and the geometric mean diameter (GMD), by the equation 2.

$$
\begin{aligned}
& \text { MWD }=\sum_{i=1}^{n}(M D i . x i) \\
& \text { GMD }=10 \sum_{i=1}^{n}(M D i \log x i) / \sum_{i=1}^{n} M D i
\end{aligned}
$$

where:

MDi $=$ the proportion of aggregates in the different classes of sieves, and

$x i=$ the average value of aggregates of each class $(\mathrm{mm})$.

To determine the morphological characteristics, aggregates were collected in the screens of 4.76 to 9.52 $\mathrm{mm}$ and 2.00 to $4.76 \mathrm{~mm}$, in the layers $0-0.05,0.05-0.10,0.10$ to $0.15,0.15-0.20$ and $0.20-0.30 \mathrm{~m}$. At the time of sample collection, the aggregates were separated by sieving with ten light and constant movements, then they were packed in a smooth and rigid plastic container, protected by two foam layers (top and bottom) and transported without agitation that could change the original structure. The samples were air dried before being subjected to analysis.

Approximately 60 aggregates were randomly distributed on a scanner (HP 6000C, with optical resolution of $1200 \mathrm{dpi}$ ) for imaging. The images were processed using the software Quantporo. The resolution used in the image acquisition was $300 \mathrm{dpi}$, for both classes of aggregates analyzed. This resolution has the capacity to process and analyze different images and measure or evaluate the morphological characteristics of objects in general.

The RGB colour system was used in the preparation of images for further analysis, with the colors formed by the combination of wavelengths of red, green and blue. These colors according to Viana (2001), are combined to produce color images and the information contained in each pixel is composed by their relative values.

The RGB image is then subjected to filtering by the median filter, that operates by replacing the values of each pixel by the median value of the pixels in the surroundings. Its main effect is to reduce stray pixels, most of these, constituting noises that cause distortions, especially in perimeter measures.

All images were converted into their binary form, i.e., constituted only by the colors black and white, through the threshold by which the images were segmented using the threshold technique. The images can be obtained using any image software and after the processing by Quantporo.

The variables evaluated in the aggregates were: Area (AR): corresponding to the number of pixels of the polygon; Perimeter (PER): length of the projection of the outer limit of the aggregate; Appearance (APP), which provides the result between zero and one, and as the higher the value, the greater the degree of rounding; Elongation (ELO), which is the ratio between the length of the smaller axis and the length of the larger axis.

The results were submitted to variance analysis and when the $\mathrm{F}$ test showed significance, the treatment means were compared by the Tukey test at $5 \%$ probability, using the statistical software Assistat (Silva \& Azevedo, 2006).

\section{RESULTS AND DISCUSSION}

After 55 months of the implementation of the management systems and gypsum application, there was significant effect on following aggregate characteristics: geometric mean diameter, mean weight diameter, elongation, aspect, area and perimeter.

There was interaction of soil management with the residual effect of gypsum for geometric mean diameter (GMD), and influence only of the type of soil management for this variable (Table 1), and no effect for mean weight diameter (MWD). The soil management that had higher GMD was no-tillage with and without residual action of gypsum. Flores et al. (2008) analyzed the structural recovery of the soil by the no-tillage system and also found similar effect, resulting from the untilled surface layer. Possibly, the decrease observed in conventional tillage is due to the greater degree of tillage, also observed by Carvalho Filho et al. (2007). According to Wendling et al. (2005), the use of characteristics such as GMD and MWD to analyze the effects of management systems allow greater sensitivity in assessing soil structure.

There was significant interaction $(\mathrm{p}<0.05)$ between the layer and soil management (Table 2). The no-tillage 
system showed higher values of geometric mean diameter in the layers 0-0.05, 0.05-0.10 and 0.10-0.15 m, and for mean weight diameter in the layers $0-0.05$ and $0.05-0.10 \mathrm{~m}$, compared with the conventional planting, which agreed with Calegari et al. (2006), who observed the same trend. However, within the type of management itself, it was found that, the depth increases with the diameter of the aggregates, which corroborates the data of Sousa Neto et al. (2008) and Salton et al. (2008) These authors found that this behavior is due to the organic matter content of the soil, because there is a decrease in the amount of this cementing agent of aggregates with increasing depth.

Significant effects for the morphological attributes of the aggregates retained on the sieve mesh from 4.76 to $9.52 \mathrm{~mm}$. The residual effect of gypsum increased the elongation of the aggregates (Table 3), which expresses the relationship between the length of the minor axis and the length of the longest axis, in which the higher its value, the smaller the difference between the lengths of perpendicular axes and the lower the elongation.

The attribute elongation showed values below 1.0, inferring that the aggregates have a more polyhedral shape, confirming results obtained by Melo et al. (2008). According to these authors, the elongation can occurs depending on the mineralogical composition, mainly in Oxisols, by the presence of kaolinite.

Table 1. Geometric mean diameter of aggregates in an Oxisol under different management and residual effect of gypsum

\begin{tabular}{|c|c|c|}
\hline GYPSUM & $\begin{array}{l}\text { No-tillage } \\
\text { System }\end{array}$ & $\begin{array}{c}\text { Conventional } \\
\text { system }\end{array}$ \\
\hline$\left(\mathrm{kg} \mathrm{ha}^{-1}\right)$ & \multicolumn{2}{|c|}{$\mathbf{m m}$} \\
\hline 0 & $6.10 \mathrm{aA}$ & $5.04 \mathrm{bA}$ \\
\hline 2000 & $5.92 \mathrm{aA}$ & $4.88 \mathrm{bA}$ \\
\hline $\mathrm{CV} \% \mathrm{a}$ & \multicolumn{2}{|c|}{15.09} \\
\hline $\mathrm{CV} \% \mathrm{~b}$ & \multicolumn{2}{|c|}{21.58} \\
\hline
\end{tabular}

Means followed by the same small letter in the row and capital letter in the column are not significantly different by the tests of $F$ and Tukey $(\mathrm{P}<0.05)$.
The stacking of the units of dehydrated 1:1 minerals, such as kaolinite, may promote the approaching of ions $\mathrm{O}^{2-}$ and $\mathrm{OH}^{-}$. This effect makes the mineral more cohesive and less crystalline, leading to a change in the direction of the expansion of the structure and to a preferential direction of growth, making it longer and wider. The shape or the relations of length of the axes partly controls the behavior of the axes during transport and deposition, while rounding (or angularity) reflects the distance and accuracy of the transport. Thus, aggregates that have characteristics of greater elongation provide to soils greater resistance to particle transport, meaning less erosion.

The attribute aspect (Table 4) imparts results between zero and one, in which the higher the value obtained, the higher the degree of roundness. It is evident that the conventional tillage promoted higher degree of roundness at the depth of 0.05-0.10 m, compared with no-tillage.

There was greater roundness of the aggregate and reduction in roughness in the conventional tillage (Table 4). This have been more pronounced at a depth of 0.05 to $0.10 \mathrm{~m}$, probably because the action of the harrow in destroying the edges of these aggregates, or by the effect of incorporation of aggregates that were on the surface, and therefore susceptible to the dispersing water droplets from the rain.

The aspect also varied within each system. The conventional tillage had greater value at the depth of 0.05 $0.10 \mathrm{~m}$, but did not differ from that recorded at depths of $0.05-0.10,0.10-0.15$ and $0.20-0.30 \mathrm{~m}$, and these did not differ from that at the depth of $0.15-0.20 \mathrm{~m}$. For the no-tillage, the highest value was found at a depth of $0.20-0.30 \mathrm{~m}$, but this value did not differ significantly from the depths of 0 $0.05,0.10-0.15$ and $0.15-020 \mathrm{~m}$. The depth that showed the lowest value of surface roughness was $0.05-0.10 \mathrm{~m}$ (Table 4).

Olzeviski et al. (2004) argued that the index of roundness in management systems that cause less soil disturbance must have lower values, because this index

Table 2. Geometric mean diameter and mean weight diameter of the aggregates of an Oxisol under different management systems and at different depths

\begin{tabular}{|c|c|c|c|c|}
\hline \multirow{2}{*}{ Depth (m) } & No-tillage & Conventional Tillage & No-tillage & ConventionalTillage \\
\hline & \multicolumn{2}{|c|}{ GMD (mm) } & \multicolumn{2}{|c|}{ MWD (mm) } \\
\hline $0-0.05$ & $7.44 \mathrm{aA}$ & $5.06 \mathrm{bA}$ & $7.96 \mathrm{aA}$ & $6.56 \mathrm{bA}$ \\
\hline $0.05-0.10$ & $7.10 \mathrm{aAB}$ & $5.44 \mathrm{bA}$ & $7.79 \mathrm{aA}$ & $6.82 \mathrm{bA}$ \\
\hline $0.10-0.15$ & $6.45 \mathrm{aB}$ & $5.39 \mathrm{bA}$ & $7.36 \mathrm{aA}$ & $6.79 \mathrm{aA}$ \\
\hline $0.15-0.20$ & $5.12 \mathrm{aC}$ & $4.92 \mathrm{aA}$ & $6.33 \mathrm{aB}$ & $6.28 \mathrm{aA}$ \\
\hline $0.20-0.30$ & $3.94 \mathrm{aD}$ & $3.99 \mathrm{aB}$ & $5.45 \mathrm{aC}$ & $5.53 \mathrm{aB}$ \\
\hline $\mathrm{CV} \% \mathrm{a}$ & 15.09 & & 11.26 & \\
\hline $\mathrm{CV} \% \mathrm{c}$ & 10.45 & & 7.40 & \\
\hline
\end{tabular}

Means followed by the same small letter in the row and capital letter in the column are not significantly different by the tests of $F$ and Tukey $(\mathrm{P}<0.05)$.

Rev. Ceres, Viçosa, v. 59, n.6, p. 859-866, nov/dez, 2012 
is dependent on the perimeter measure. Thus, larger roundness values must be found for aggregates from management systems that are more aggressive to the structure, since these tend to lose the roughness of the outer surface, thus reducing the perimeter.

The no-tillage system provided a significant increase in aggregate size compared with the conventional tillage (Table 5). Similarly to the aggregate area, the no-tillage showed greater perimeter, but when the attribute elongation was evaluated, no significant difference was found between the systems.

The aggregate area is an important attribute in the structural characterization of the soil, since an aggregate of greater area means that the soil is better able to withstand fragmentation caused by winds, action of raindrops, topography, surface runoff, animal trampling and compression-induced by tractors and agricultural implements.

The larger area of soil aggregates in no-tillage may be associated with the organic matter, agreeing with reports by Olzeviski et al. (2004). These authors observed that no-tillage tended to larger aggregate areas compared with the conventional system, which uses harrows, moldboard plow, disk plow and disk ripper, since the notillage is a system that causes less damage to the soil structure, and the conventional system, in this case the disk plow, breaks and pulverizes the soil aggregates.

Table 3. Elongation of the aggregates of an Oxisol retained in sieve meshes ranging from 9.52 to $4.76 \mathrm{~mm}$, with and without residual effect of gypsum

\begin{tabular}{lc}
\hline GYPSUM $\left(\mathbf{k g ~ h a}^{-1}\right)$ & Elongation \\
\hline 0 & $0.6820 \mathrm{~b}$ \\
2000 & $0.6911 \mathrm{a}$ \\
\hline $\mathrm{CV} \%$ & 2.08 \\
\hline
\end{tabular}

Means showing different letters are significantly different by the Tukey's test at $5 \%$ probability.

Table 4. Morphological aspect of aggregates of an Oxisol retained in sieve meshes ranging from 9.52 to $4.76 \mathrm{~mm}$ in different types of soil management and depths

\begin{tabular}{lcc}
\hline \multirow{2}{*}{ Depth (m) } & No-tillage & Conventional tillage \\
\cline { 2 - 3 } & \multicolumn{2}{c}{ Aspect } \\
\hline $0-0.05$ & $0.8371 \mathrm{aAB}$ & $0.8513 \mathrm{aA}$ \\
$0.05-0.10$ & $0.8161 \mathrm{bB}$ & $0.8360 \mathrm{aAB}$ \\
$0.10-0.15$ & $0.8291 \mathrm{aAB}$ & $0.8347 \mathrm{aAB}$ \\
$0.15-0.20$ & $0.8368 \mathrm{aAB}$ & $0.8242 \mathrm{aB}$ \\
$0.20-0.30$ & $0.8406 \mathrm{aA}$ & $0.8333 \mathrm{aAB}$ \\
\hline
\end{tabular}

$\mathrm{CV}$ a \%CV c \% 1.791 .95

Means followed by the same small letter in the row and capital letter in the column are not significantly different by the test of Tukey $(\mathrm{P}<0.05)$.
Comparing the perimeter of the aggregates in the two systems, it appears that the conventional planting caused breakage of aggregates, making them smaller (Table 5). As the perimeter has intrinsic relationship with the area of the aggregates, these smaller areas will occur due to the action of farming practices and erosive agents (Cremon $e t$ al., 2009).

Table 6 shows the results of the unfolding of the interaction between soil tillage and depth, in the evaluation of morphological characteristics of the aggregates in the range of sieve meshes between 4.76 and $2.00 \mathrm{~mm}$.

The area of aggregates retained in this range was greater in no-tillage at a depth of 0-0.05 m compared with the conventional tillage, agreeing with the findings of Cremon (2007), in which the input of plant material in the soil and the non-revolving increased the aggregate area. However, at the other depths, there was no significant difference among tillage systems.

The aggregate area for the different systems varied significantly as a function of depth. In the no-tillage system, the depths of 0-0.05 and 0.05-0.10 m showed larger areas, while the depth of $0.20-0.30 \mathrm{~m}$ showed the lowest rates of aggregate area. In the conventional tillage, the largest area was at a depth of $0.10-0.15 \mathrm{~m}$, and the smaller areas were at a depth of 0.20-0.30 m. This behavior also occurred in the no-tillage. The elongation (Table 6) was higher for the conventional tillage at the depths, in descending order, of $0-0.05$, $0.10-0.15$ and $0.05-0.010 \mathrm{~m}$.

The attribute aspect, which indicates the degree of roughness of the aggregates, differed significantly among the systems only at the depth of 0.05-0.10 m (Table 6). In the conventional tillage system, this value was higher, probably because this system causes the edges of the aggregates to break at this depth. This behavior is similar to that observed for the same variable in the aggregates retained in the sieve mesh range of 9.52 to $4.76 \mathrm{~mm}$. It is noteworthy that aggregates that show this effect decrease the contact face, relatively reducing the porous space in the soil.

For the perimeter, there was significant difference between the managements only at the depth of 0-0.05 m, and the no-tillage system provided the largest perimeter, however, this attribute differed significantly within each soil management system. It was found that in the no-tillage system, there was decrease of the perimeter of aggregates with the increase of the depth. Melo et al. (2008) discuss that this effect can be attributed to the composition of Oxisols, in which the larger amounts of gibbsite, goethite and hematite favoured the increase in the aggregate area, because of the greater tendency to neutralization of the negative charges on kaolinite particles, contributing for the growth of the aggregates.

-Rev. Ceres, Viçosa, v. 59, n.6, p. 859-866, nov/dez, 2012 
For the attribute morphological aspect of aggregates, there was a significant interaction between soil management and residual effect of gypsum (Table 7), and the values for the conventional tillage system were similar to those for no-tillage without the residual effect of gypsum.

In the presence of the residual of gypsum, the aspect of the aggregate was higher in the conventional system. In the no-tillage, the residual effect of gypsum was smaller, which is desirable because the aggregates that exhibit this characteristic are rougher. The roughness allows that the disintegration ability and transport of particles by the action of soil runoff is reduced, leading to deposition of erosion sediments at the site of the phenomenon occurrence by means of the microdepressions formed by the roughness (Bertol et al., 1987, Bertol et al., 1989; Castro et al., 2006).

The interaction between the residual effect of gypsum and depth is shown in Table 8. The residual effect of gypsum caused significant difference for the morphological variables area and perimeter; however, only at the depth of 0-0.05 m. The aggregate area decreased as a function of depth, both in the presence and absence of the residual effect of gypsum. At other depths, it varied as the soil profile deepened.

The aggregate area, analyzed with the use of images, was lower in the presence of gypsum. Lebron et al. (2002), working with rates of gypsum in soil columns, found a

Table 7. Aspect of the aggregates of an Oxisol retained in sieve meshes ranging from 4.76 to $2.00 \mathrm{~mm}$, under different management systems and residual effect of gypsum

\begin{tabular}{lcc}
\hline GYPSUM $\left(k^{2}\right.$ ha $\left.^{-1}\right)$ & No-tillage & Conventional Tillage \\
\hline 0 & $0.8238 \mathrm{aA}$ & $0.8251 \mathrm{aA}$ \\
2000 & $0.8291 \mathrm{bA}$ & $0.8308 \mathrm{aA}$ \\
\hline Cv a $\%$ & 2.931 .51 & \\
\hline
\end{tabular}

\section{$\mathrm{Cvb} \%$}

Means followed by the same small letter in the row and capital letter in the column are not significantly different by the test of Tukey $(\mathrm{P}<0.05)$.

Table 5. Area, perimeter and elongation of aggregates of an Oxisol retained in sieve meshes ranging from 9.52 to $4.76 \mathrm{~mm}$, as a function of the management

\begin{tabular}{lccc}
\hline Management System & Area $\left(\mathbf{C m}^{2}\right)$ & Perimeter $(\mathbf{C m})$ & Elongation \\
\hline No-Tillage & $0.4118 \mathrm{~A}$ & $2.7190 \mathrm{~A}$ & $0.6824 \mathrm{~A}$ \\
Conventional Tillage & $0.3646 \mathrm{~B}$ & $2.5352 \mathrm{~B}$ & $0.6907 \mathrm{~A}$ \\
\hline $\mathrm{CV}(\%) \mathrm{a}$ & 10.09 & 6.79 & 7.91 \\
\hline $\mathrm{CV}(\%) \mathrm{c}$ & 15.26 & 7.40 & 2.08 \\
\hline
\end{tabular}

Means followed by the same small letter in the column are not significantly different by the $F$ test at $5 \%$ probability.

Table 6. Morphological characteristics of the aggregates of a Oxisol retained in sieve meshes ranging from 9.52 to $4.76 \mathrm{~mm}$, under different management systems and different depths

\begin{tabular}{|c|c|c|c|c|}
\hline \multirow[t]{2}{*}{ Depth (m) } & No-tillage & Conventional Tillage & No-tillage & Conventional Tillage \\
\hline & \multicolumn{2}{|c|}{ Area $\left(\mathbf{c m}^{2}\right)$} & \multicolumn{2}{|c|}{ Elongation } \\
\hline $0-0.05$ & $0.1111 \mathrm{aA}$ & $0.0784 \mathrm{bB}$ & $0,6969 \mathrm{bAB}$ & $0,7468 \mathrm{aA}$ \\
\hline $0.05-0.10$ & $0.1004 \mathrm{aAB}$ & $0.0874 \mathrm{aAB}$ & $0,6730 \mathrm{bB}$ & $0,7033 \mathrm{aB}$ \\
\hline $0.10-0.15$ & $0.0953 \mathrm{aBC}$ & $0.0943 \mathrm{aA}$ & $0,6759 \mathrm{bB}$ & $0,7127 \mathrm{aAB}$ \\
\hline $0.15-0.20$ & $0.0915 \mathrm{aBC}$ & $0.0926 \mathrm{aAB}$ & $0,7191 \mathrm{aA}$ & $0,7092 \mathrm{aB}$ \\
\hline $0.20-0.30$ & $0.0829 \mathrm{aC}$ & $0.0789 \mathrm{aB}$ & $0,7158 \mathrm{aA}$ & $0,7353 \mathrm{aAB}$ \\
\hline $\mathrm{CV}(\%) \mathrm{b}$ & 22.56 & & 4.03 & \\
\hline \multirow[t]{2}{*}{$\mathrm{CV}(\%) \mathrm{c}$} & 11.28 & & 3.60 & \\
\hline & Aspect & & Perimeter $(\mathrm{cm}$ & \\
\hline $0-0.05$ & $0.8298 \mathrm{aAB}$ & $0.8366 \mathrm{aA}$ & $1,3922 \mathrm{aA}$ & $1,1165 \mathrm{bB}$ \\
\hline $0.05-0.10$ & $0.8149 \mathrm{bB}$ & $0.8380 \mathrm{aA}$ & $1,3500 \mathrm{aAB}$ & $1,2219 \mathrm{aAB}$ \\
\hline $0.10-0.15$ & $0.8239 \mathrm{aAB}$ & $0.8130 \mathrm{aB}$ & $1,3100 \mathrm{aAB}$ & $1,2652 \mathrm{aA}$ \\
\hline $0.15-0.20$ & $0.8235 \mathrm{aAB}$ & $0.8173 \mathrm{aAB}$ & $1,2398 \mathrm{aBC}$ & $1,2565 \mathrm{aA}$ \\
\hline $0.20-0.30$ & $0.8402 \mathrm{aA}$ & $0.8348 \mathrm{aAB}$ & $1,1810 \mathrm{aC}$ & $1,1267 \mathrm{aB}$ \\
\hline $\mathrm{CV}(\%) \mathrm{b}$ & 2.93 & & 10.88 & \\
\hline $\mathrm{CV}(\%) \mathrm{c}$ & 1.89 & & 6.44 & \\
\hline
\end{tabular}

Means followed by the same small letter in the row and capital letter in the column are not significantly different by the test of Tukey (P $<0.05)$. 
Table 8. Morphological characteristics of the aggregates of a Oxisol retained in sieve meshes ranging from 4.76 to $2.00 \mathrm{~mm}$, under different management systems and different depths

\begin{tabular}{|c|c|c|c|c|}
\hline \multirow{2}{*}{ Depth (m) } & 0 kg ha $^{-1}$ & $2000 \mathrm{~kg} \mathrm{ha}^{-1}$ & 0 kg ha $\mathbf{~}^{-1}$ & $2000 \mathrm{~kg} \mathrm{ha}^{-1}$ \\
\hline & \multicolumn{2}{|c|}{ Area cm $^{2}$} & \multicolumn{2}{|c|}{ Perimeter cm } \\
\hline $0-0.05$ & $0.1011 \mathrm{aA}$ & $0.0884 \mathrm{abB}$ & $1.3174 \mathrm{aA}$ & $1.1913 \mathrm{bAB}$ \\
\hline $0.05-0.10$ & $0.0901 \mathrm{aAB}$ & $0.0976 \mathrm{aA}$ & $1.2708 \mathrm{aAB}$ & $1.3010 \mathrm{aA}$ \\
\hline $0.10-0.15$ & $0.0988 \mathrm{aA}$ & $0.0908 \mathrm{aAB}$ & $1.3194 \mathrm{aA}$ & $1.2558 \mathrm{aAB}$ \\
\hline $0.15-0.20$ & $0.0890 \mathrm{aAB}$ & $0.0951 \mathrm{aA}$ & $1.2198 \mathrm{aAB}$ & $1.2765 \mathrm{aA}$ \\
\hline $0.20-0.30$ & $0.0828 \mathrm{aB}$ & $0.0790 \mathrm{aB}$ & $1.1602 \mathrm{aB}$ & $1.1475 \mathrm{aB}$ \\
\hline $\mathrm{Cv} \% \mathrm{~b}$ & 11.9611 .38 & & 6.446 .73 & \\
\hline
\end{tabular}

$\mathrm{Cv} \% \mathrm{c}$

Means followed by the same small letter in the row and capital letter in the column are not significantly different by the test of Tukey (P $<0.05$ ).

trend of the gypsum a smaller aggregate area. Gypsum increases the concentration of electrolytes in the soil solution. This more concentrated solution compresses the double electric layer, providing calcium to the exchange complex (Dontsova \& Norton, 2002), which favours soil aggregation. Importantly, the area of aggregates, as well as the perimeter, has a direct effect on the pore space, because aggregates of smaller areas may condition the soil to compaction and/or consolidation, and impair the development of roots and seedlings.

\section{CONCLUSIONS}

The no-tillage system provided the largest geometric diameters, mean weight diameter, area and perimeter of aggregates.

The aggregates were rougher and provided greater perimeter up to a depth of $0-0.05 \mathrm{~m}$.

The combination of no-tillage and residual effect of gypsum provided rougher aggregates.

\section{REFERENCES}

Albuquerque JA, Cassol EA \& Reinert DJ (2000) Relação entre a erodibilidade em entressulcos e estabilidade dos agregados. Revista Brasileira de Ciência do Solo, 24:141-51.

Assis RL \& Bahia VG (1998) Práticas mecânicas e culturais de recuperação de características físicas dos solos degradados pelo cultivo. Informe Agropecuário, 19:71-78.

Bayer C \& Mielniczuk J (1999) Dinâmica e função da matéria orgânica. In: Santos G de A \& Camargo FA de O (Eds.) Fundamentos da matéria orgânica do solo: ecossistemas tropicais e subtropicais. Porto Alegre, Genesis. p.09-26.

Bertol I, Cogo NP \& Levien R (1987) Relações da erosão hídrica com métodos de preparo do solo na ausência e na presença de cobertura por resíduo cultural de trigo. Revista Brasileira de Ciência do Solo, 11:187-192.

Bertol I, Cogo NP \& Levien R (1989) Cobertura morta e métodos de preparo do solo na erosão hídrica em solos com crosta superficial. Revista Brasileira de Ciência do Solo, 13:373-379.

Bronick CJ \& Lal R (2005) Soil structure and management: a review. Geoderma, 124:3-22.
Calegari A, Castro Filho C, Tavares Filho J, Ralisch R \& Guimarães MF (2006) Melhoria da agregação do solo através do sistema plantio direto. Semina Ciências Agrárias, 27:147-158.

Calonego JC \& Rosolem CA (2008) Estabilidade de agregados do solo após manejo com rotações de culturas e escarificação. Revista Brasileira de Ciência do Solo, 32:1399-1407.

Carvalho Filho A, Silva RP, Centurion JF, Carvalho LCC \& Lopes A (2007) Agregação de um Latossolo Vermelho submetido a cinco sistemas de preparo do solo em Uberaba-MG. Engenharia Agrícola, 27:317-325.

Castilho JAF, Navia JFE \& Menjivar JCF (2008) Estimación de la estabilidad estructural de dos suelos al sur de Colômbia com diferentes tipos de manejo. Acta Agronómica, 57:31-34.

Castro LG, Cogo NP \& Volk LBS (2006) Alterações na rugosidade superficial do solo pelo preparo e pela chuva e sua relação com a erosão hídrica. Revista Brasileira de Ciência do Solo, 30:339-352.

Castro Filho C, Muzilli O \& Podanoschi AL (1998) Estabilidade dos agregados e sua relação com o teor de carbono orgânico num Latossolo Roxo distrófico, em função de sistemas de plantio, rotações de cultura e métodos de preparo de das amostras. Revista Brasileira de Ciência do Solo, 22:527-538.

Cremon C (2007) Levantamento dos atributos de um Entisol influenciados por diferentes sistemas de cultivo de arroz no norte da Itália. Tese de Doutorado. Universidade Federal da Grande Dourados, Dourados. 85p.

Cremon C, Serafim ME \& Rosa Junior EJ (2009) Análise micromorfométrica dos agregados de um Latossolo Vermelho distroférrico sob diferentes sistemas de manejo. Acta Scientiarum Agronomy, 31:139-146.

Dontsova KM \& Norton LD (2002) Clay dispersion, infiltration and erosion as influenced by exchangeable $\mathrm{Ca}$ and $\mathrm{Mg}$. Soil Science Society of America Journal, 167:184-193.

D’Andréa AF, Silva MLN, Curi N, Siqueira JO \& Carneiro MAC (2002) Atributos de agregação indicadores da qualidade do solo em sistemas de manejo na região dos cerrados no sul do Estado de Goiás. Revista Brasileira de Ciência do Solo, 26:1047-1054.

Empresa Brasileira de Pesquisa Agropecuária - Embrapa (1997) Manual de métodos de análise de solos. $2^{\mathrm{a}}$ ed. Rio de Janeiro, Embrapa/CNPS. 212p.

Empresa Brasileira de Pesquisa Agropecuária - Embrapa (1999) Centro Nacional de Pesquisa de Solos. Sistema Brasileiro de classificação de solos. Rio de janeiro, Embrapa. 412p.

Flores CA, Reinert DJ, Reichert JM, Albuquerque JÁ \& Pauletto EA (2008) Recuperação da qualidade estrutural, pelo sistema plantio direto, de um Argissolo Vermelho. Ciência Rural, 38:2164-2172.

-Rev. Ceres, Viçosa, v. 59, n.6, p. 859-866, nov/dez, 2012 
Horn R \& Smucker A (2005) Structure formation and its consequences for gas and water transport in unsaturated arable and forest soils. Soil Tillage, 82:5-14.

Gajic B, Dugalig G \& Djurovic N (2006) Comparison of soil organic matter content, aggregate composition and water stability of gleyic fluvisol from adjacent forest and cultivated areas. Agronomy Research, 4:499-508.

Kemper WD \& Chepil WS (1965) Size distribution of aggregation. In: Black CA (Ed.) Methods of soil analysis. Madison, American Society of Agronomy. p. 499-510.

Lacerda N, Zero VM, Barilli J, Moraes MH \& Bicudo SJ (2005) Efeito de sistemas de manejo na estabilidade de agregados de um Nitossolo Vermelho. Engenharia Agrícola, 25:686-695.

Lebron I, Suarez DL \& Yoshida T (2002) Gypsum effect on the aggregate size and geometry of three sodic soils under reclamation. Soil Science, 66:92-98.

Matos ES, Mendonça ES, Leite LFC \& Galvão JCC (2008) Estabilidade de agregados e distribuição de carbono e nutrientes em Argissolo sob adubação orgânica e mineral. Pesquisa Agropecuária Brasileira, 43:1221-1230.

Melo VF, Moura R, Toledo FH, Lima VC \& Ghidin AA (2008) Morfologia de agregados de Latossolo Bruno e Vermelho do estado do Paraná, avaliada por imagens obtidas em scanner. Revista Brasileira de Ciência do Solo, 32:85-99.

Olzeviski N, Costa LM, Fernandes Filho EI, Ruiz HA, Alvarenga RC \& Cruz JC (2004) Morfologia de agregados do solo avaliada por meio de análise de imagens. Revista Brasileira de Ciência do Solo, 28:901-909.

Palmeira PRT, Paluleto EA, Teixeira CFA, Gomes AS \& Silva JB (1999) Agregação de um Planossolo submetido a diferentes manejos de cultivo. Revista Brasileira de Ciência do Solo, 23:189195.

Pulleman MM, Six J, Uyl A, Marinissen JCY \& Jongmans AG (2005) Earthworms and management affect organic matter incorporation and microaggregate formation in agricultural soils. Applied Soil Ecology, 29:01-15.

Reicherdt JM, Veiga M \& Cabeda MSV (1993) Índices de estabilidade de agregados e suas relações com características e parâmetros de solo. Revista Brasileira de Ciência do Solo, 17:283-290.
Rosa Junior EJ, Martins RMG, Rosa YBCJ \& Cremon C (2006) Calcário e gesso como condicionantes físico e químico de um solo de cerrado sob três sistemas de manejo. Pesquisa Agropecuária Tropical, 36:37-44

Rosa Junior EJ, Vitorino ACT \& Vitorino PFP (1994) Efeito da calagem, gessagem e adubação fosfatada sobre algumas características físicas de um Latossolo Roxo Distrófico de Dourados, MS. Revista Científica, 1:05-12.

Salton JC, Mielniczuk J, Bayer C, Boeni M, Conceição PC, Fabricio AC, Macedo MCM \& Broch DL (2008) Agregação e estabilidade de agregados do solo em sistemas agropecuários em Mato Grosso do Sul. Revista Brasileira de Ciência do Solo, 32:11-21.

Shainberg I \& Levy GJ (1995) Infiltration and seal formation processes. In: Agassi M (Ed.) Soil erosion, conservation, and rehabilitation. New York, Marcel Dekker. p.1-22.

Silva FAS \& Azevedo CAV (2006) A New Version of The AssistatStatistical Assistance Software. In: World Congress on Computers in Agriculture, Orlando. Anais, American Society of Agricultural Engineers. p. 393-396.

Silva CL \& Kato E (1997) Efeito do selamento superficial na condutividade hidráulica saturada da superfície de um solo sob cerrado. Pesquisa Agropecuária Brasileira, 32:213-220.

Sousa Neto EL, Andrioli I, Beutler NA \& Centurion JF (2008) Atributos físicos do solo e produtividade de milho em resposta a culturas de pré-safra. Pesquisa Agropecuária Brasileira, 43:255260 .

Souza FR, Rosa Junior EJ, Fietz CR, Bergamin AC, Venturoso LR \& Rosa YBCJ (2010) Atributos físicos e desempenho agronômico da cultura da soja em um Latossolo Vermelho distroférrico submetido a dois sistemas de manejo. Ciência e Agrotecnologia, 34:1357-1364.

Viana JHM (2001) Análise de imagens micropedológicas com utilização do programa Quantporo e sua aplicação ao estudo de umedecimento e secagem em amostras de Latossolos. Dissertação de Mestrado. Universidade Federal de Viçosa, Viçosa. 70p.

Wendling B, Jucksch I, Mendonça ES \& Neves JCL (2005) Carbono orgânico e estabilidade de agregados de um Latossolo Vermelho sob diferentes manejos. Pesquisa Agropecuária Brasileira, 40:487-494. 